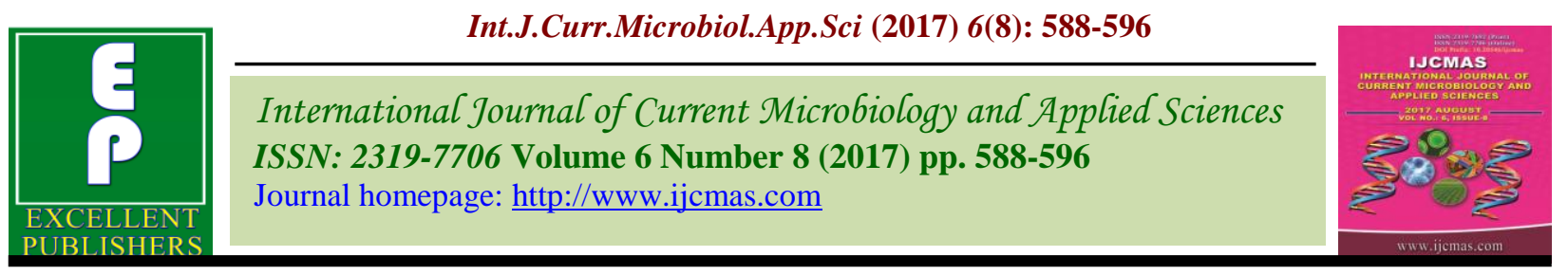

Original Research Article

https://doi.org/10.20546/ijcmas.2017.608.076

\title{
Characterization of Phosphate Solubilizing Bacteria Isolated from Mine Tailings of Zawar Mines, Udaipur, India
}

\author{
Monica Sen and Harshada Joshi* \\ Department of Biotechnology, Vigyan Bhawan, Block B, Mohanlal Sukhadia \\ University, Udaipur, Rajasthan, India \\ *Corresponding author
}

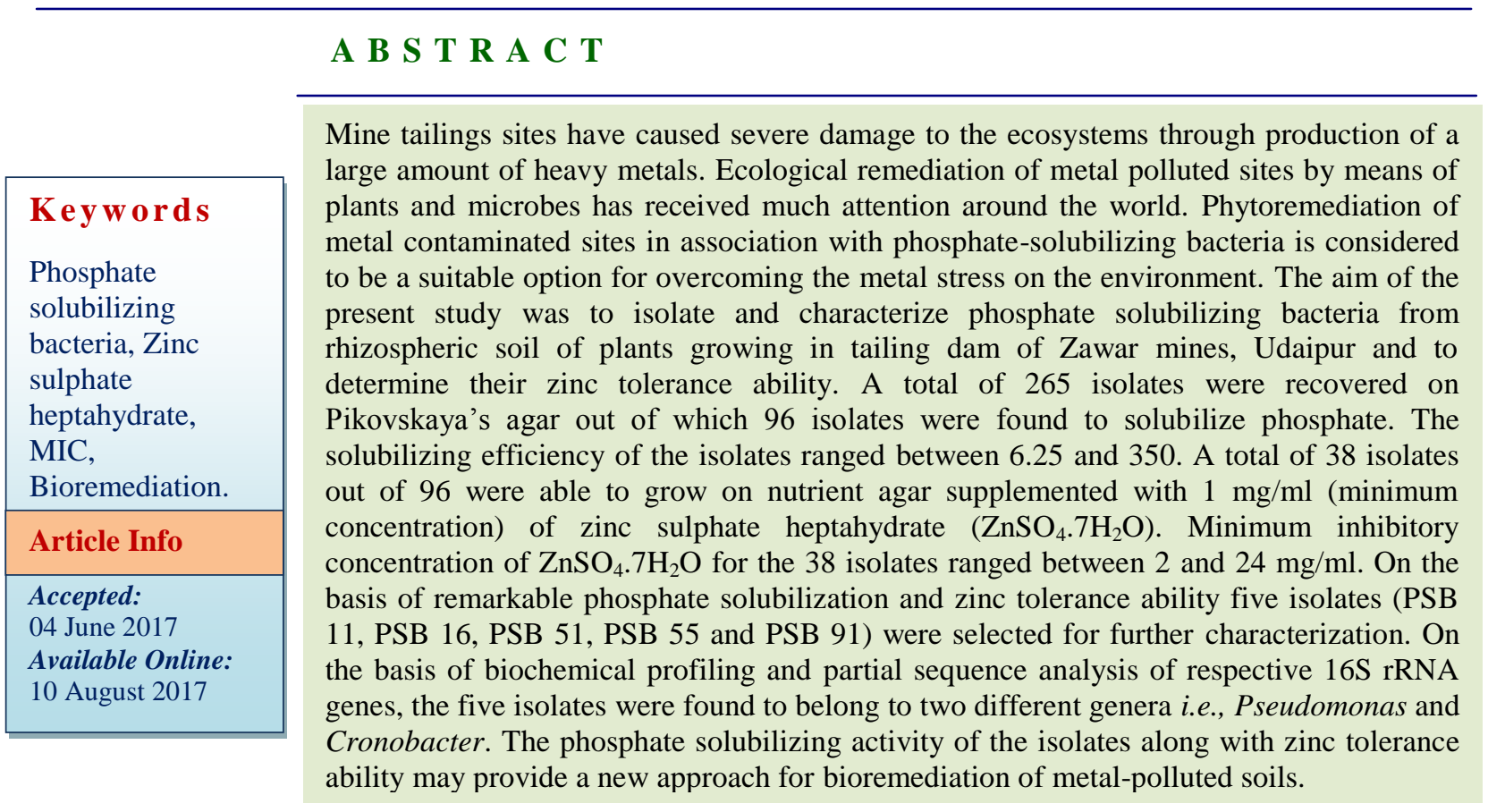

\section{Introduction}

Pollution of biosphere by toxic heavy metals has increased rapidly since the beginning of industrial revolution. Various anthropogenic sources like smelters, mining, application of metal containing pesticides, fertilizers and sewage sludge etc. has resulted in contaminated soil within creased levels of metals (Giller et al., 2001). Elevated concentrations of metals such as arsenic, cadmium, copper, manganese, lead, and zinc $(1-50 \mathrm{~g} / \mathrm{kg})$ are usually found in mine tailings
(Mendez et al., 2007) where they frequently cross the established toxic threshold values. These heavy metals are supposed to contaminate the lands in the vicinity of mine tailings and have been regarded as one of the most severe hazards to environmental and human health (Wcislo et al., 2002). These problems have raised an urgent need for treatment of heavy metal contaminated lands. The remediation of heavy metal contaminated soils is a challenging task because metals are 
not easily degraded; the danger they pose is aggravated by their almost indefinite persistence in the environment. Until now, methods used for the remediation of heavymetal contaminated soils, such as physical separation, acid leaching or electrochemical processes are not suitable for practical applications, because of their high cost and low efficiency.

Phytoextraction and phytostabilization of metals in metal-contaminated soils have received considerable attention due to their low cost and high efficiency. However, heavy metals at elevated levels are generally toxic to most plants, impairing their metabolism and reducing plant growth.

Bioremediation process using microbial biomass has offered an alternative approach over the conventional methods. Microbes residing in the rhizosphere of plants can be exploited in remediation processes owing to their ability of increasing nutrient uptake and reducing metal toxicity through biosorption (trapping mobile heavy metals in their exopolysacharide layer and cell wall).

Phosphorous solubilizing microorganisms (PSM) are one such group of rhizobacteria which are capable of solubilizing the inorganic P from insoluble source as well as reduces environmental pollution and promotes sustainable agriculture. PSM are ubiquitous in soils and could play an important role in supplying $\mathrm{P}$ to the plants where plant available $\mathrm{P}$ content in soil is less by following different mechanisms like lowering of $\mathrm{pH}$ by acid production, ion chelation and exchange reactions in the growth environment.

They restrict the movement of heavy metals to plant organs and ameliorate conditions for plantation in metal-contaminated lands (Ahemad, 2012; Glick, 2012). Their use is cost effective and is considered environmentally friendly.

Zawar mines $\left(24^{\circ} 21^{\prime} \mathrm{N} ; 73^{\circ} 41^{\prime} \mathrm{E}\right)$ are an ancient zinc smelting site, $40 \mathrm{kms}$ southeast of Udaipur (Rajasthan, India). The waste released from the mines contains huge metal content which is dumped in the tailing dams. The released metals $(\mathrm{Pb}, \mathrm{Zn}, \mathrm{Cd}$, etc.) get accumulated in soil and adversely affect the physicochemical properties of soils leading to loss of soil fertility. Therefore, an attempt has been made to isolate some efficient phosphate solubilizers from the rhizosphere of wild plants growing in the contaminated area of Zawar mines tailing and to determine their zinc tolerant abilities.

\section{Materials and Methods}

\section{Collection of samples}

The rhizospheric soil samples were collected from wild plants (Calotropis, Acacia and Tridex) growing in tailing dam of Zawar mines, Udaipur, India. Collection of these samples was done in sterilized zipper polythenes and transported to the Molecular Microbiology Laboratory at the Department of Biotechnology, Mohanlal Sukhadia University, Udaipur. The soil samples were stored at $4^{\circ} \mathrm{C}$ and were further processed within $24 \mathrm{~h}$ for isolation of phosphate solubilizing bacteria.

\section{Isolation of phosphate solubilizing bacteria}

Phosphate solubilizing bacteria were isolated from the rhizospheric soil samples on Pikovskaya's (PVK) agar (Pikovskaya, 1948) containing tri-calcium phosphate (TCP) using pour plate method. The plates were incubated at $37^{\circ} \mathrm{C}$ for 2-3 days.

The isolates forming clear halo zone of clearance (Pikovskaya's medium) around 
their colonies were considered as phosphate solubilizers. These isolates were purified and maintained on nutrient agar slants.

\section{Determination of solubilizing efficiency}

The phosphate solubilizing efficiency was estimated on PVK agar by using spot assay method. The plates were incubated at $37^{\circ} \mathrm{C}$ for five days. The clear halo zone around the colonies was measured. The phosphate solubilization efficiency (SE) of the isolates was calculated using following formula:

Solubilizing efficiency $(\mathrm{SE})=($ Halo zone diameter/ Colony diameter) X 100 (Nguyen et al., 1992)

\section{Determination of zinc tolerance ability}

The zinc tolerant ability of phosphate solubilizing bacteria was determined by streaking them on nutrient agar containing $1 \mathrm{mg} / \mathrm{ml}$ of zinc sulphate heptahydrate. The plates were incubated at $37^{\circ} \mathrm{C}$ for $48 \mathrm{~h}$. MIC of the isolates was determined by agar plate dilution method (Luli et al., 1983). The isolates were streaked on nutrient agar supplemented with varying concentrations of zinc sulphate heptahydrate ranging from 1 to $30 \mathrm{mg} / \mathrm{ml}$. The petri plates were inoculated with the test culture and incubated at $37^{\circ} \mathrm{C}$ for $48 \mathrm{~h}$. The lowest concentration of zinc sulphate heptahydrate that inhibited the growth of bacteria was considered as MIC.

\section{Characterization of phosphate solubilizing bacteria}

The cultural characteristics of the isolates were studied on nutrient agar based on size, colour, form, elevation and margin of the bacterial colonies. The morphological characterization was based on Gram staining. Biochemical characterization of phosphate solubilizing bacteria was done by performing different biochemical tests. The molecular characterization of phosphate solubilizing bacteria was done by $16 \mathrm{~S}$ rRNA gene sequencing. The genomic DNA of all the isolates was isolated by Pospeich and Neumman's method (1995). The 16S rRNA sequence of DNA was amplified using universal primers, 27F (5'-AGAGTTTGATC CTGGCTCAG-3') and 1492R (5'CGGTTAC CTTGTTACGACTT-3') (Weisberg et al., 1991) using PCR. The amplified products were submitted to Bangalore Genei Pvt. Ltd., Bangalore (India) for sequencing. The partially sequenced genomes of the isolates were compared with available standard sequences of bacterial lineages in the NCBI Genbank using nBLAST program.

\section{Results and Discussion}

\section{Isolation of phosphate solubilizing bacteria}

A total of 41 soil samples were collected from rhizosphere of plants growing in tailing dam of Zawar mines. Out of 41 samples, 17 soil samples were collected from rhizosphere of Tridex, 12 samples from rhizospheric soil of Calotropis and remaining 12 from rhizosphere of Acacia. A total of 265 isolates were recovered on PVK agar out of which 96 produced halo zone of clearance around their colonies indicating phosphate solubilization activity. Out of 96, 35 isolates were recovered from rhizospheric soil samples of Tridex, 31 isolates from Calotropis rhizospheric soil, and 30 isolates were recovered from rhizospheric soil samples of Acacia (Fig. 1). The recovered isolates showed differences in the size of the halo zone. All the 96 isolates were purified and sub cultured on PVK agar and showed halo zone of clearance after 5 days of incubation.

\section{Phosphate solubilizing efficiency}

All the 96 isolates produced clear zone on PVK agar and showed halo clear zones of 
varying diameter after 5 days of incubation. The diameter of halo zone produced by different phosphate solubilizing isolates ranged between 0.1 to $2.8 \mathrm{~cm}$. The phosphate solubilizing efficiency (SE) of all the 96 phosphate solubilizing isolates was calculated. The SE for the isolates ranged from 6.25 to 350 . The maximum values of SE was calculated for five isolates namely PSB 55 followed by PSB 91, PSB 51, PSB 11 and PSB 16 where SE calculated were 350, 315.5, 277, 275 and 218respectively (Table 1). Several researchers have used solubilization efficiency as a screening tool for selection of potential PSB isolates. It provides a primary quantitative measure of the extent of solubilization of insoluble inorganic phosphate that a culture can induce (Chen, 2005). Literature reports SE values ranging from as high as 600 (Joseph et al., 2008) to a medium 400 (Ramachandran et al., 2002) and even lower range of $109-240$ (Onyia et al., 2013). Mursyida et al., 2015 stated that the variation in the solubilizing efficiency reflected the difference in ability of the isolates to secrete extracellular organic acids. The production of organic acids was stated to be the main mechanism in solubilizing phosphates reported by Archana et al., 2013. However, Reyes et al., 1999 reported a different mechanism of acidification during phosphate solubilization by proton extrusion associated with ammonium assimilation in the wild-type Penicillium rugulosum strain. The 96 isolates in the present study might have followed any one of the above mentioned mechanisms for phosphate solubilization.

\section{Tolerance to zinc sulphate heptahydrate}

A total of 38 out of 96 isolates were able to grow on nutrient agar supplemented with $1 \mathrm{mg} / \mathrm{ml}$ zinc sulphate heptahydrate. The remaining 58 isolates were considered to be zinc sensitive. The minimum inhibitory concentration (MIC) of all the 38 isolates for zinc sulphate heptahydrate was determined by agar plate dilution method using nutrient agar supplemented with varying concentrations of zinc sulphate heptahydrate ranging from $1 \mathrm{mg} / \mathrm{ml}$ to $30 \mathrm{mg} / \mathrm{ml}$. The MIC of 38 isolates for zinc sulphate heptahydrate ranged from $2 \mathrm{mg} / \mathrm{ml}$ to $24 \mathrm{mg} / \mathrm{ml}$ (Fig. 2). The highest MIC of $24 \mathrm{mg} / \mathrm{ml}$ was exhibited by PSB 16 followed by $21 \mathrm{mg} / \mathrm{ml}$ by PSB 11 and $15 \mathrm{mg} / \mathrm{ml}$ by PSB 51 .

Pal et al., (2005) isolated a total of 342 isolates from serpentine and non-serpentine soils of Andaman Islands, India and compared their $\mathrm{Ni}, \mathrm{Co}$ and $\mathrm{Cr}$ resistance. They reported that serpentine microflora was highly resistant than non-serpentine ones and showed a metalresistance profile of $\mathrm{Cr}>\mathrm{Ni}>\mathrm{Co}$. They also stated that microorganisms isolated from natural environments contaminated with heavy metalsoften exhibit tolerance to metal pollutants because they have adapted to such environments. The same is true for the present study where zinc tolerant isolates were recovered from heavy metal contaminated land of Zawar tailing dam. Wani et al., (2008) studied the effect of zinc tolerant plant growth promoting rhizobacteria on lentil growth and reported that isolates follow different mechanisms to tolerate the uptake of heavy metal ions.

These mechanisms include the efflux of metal ions outside the cells, accumulation and complexation of the metal ions inside the cells and reduction of toxic metals to less toxic forms which was previously explained by Outten et al., (2000). In the present study the isolates might have followed the similar mechanism for tolerating high concentrations of zinc sulphate heptahydrate. A total of 5 isolates namely PSB 11, PSB 16, PSB 51, PSB 55 and PSB 91 were selected on the basis of maximum solubilization efficiency and fairly high zinc tolerance ability and were subjected to characterization. 
Table.1 Phosphate solubilization efficiency, index and MIC of zinc sulphate heptahydrate Exhibited by phosphate solubilizing bacterial isolates

\begin{tabular}{|l|l|l|l|l|l|l|}
\hline S. No. & $\begin{array}{l}\text { PSB } \\
\text { Isolate }\end{array}$ & $\begin{array}{l}\text { Colony } \\
\text { diameter }(\mathbf{c m})\end{array}$ & $\begin{array}{l}\text { Halo zone } \\
\text { diameter }(\mathbf{c m})\end{array}$ & SI & SE (\%) & MIC \\
\hline 1 & PSB 11 & 0.8 & 2.2 & 3.75 & 275 & 21 \\
\hline 2 & PSB 16 & 1.1 & 2.4 & 3.18 & 218 & 24 \\
\hline 3 & PSB 51 & 0.9 & 2.5 & 3.77 & 277 & 15 \\
\hline 4 & PSB 55 & 0.8 & 2.8 & 4.50 & 350 & 0 \\
\hline 5 & PSB 91 & 0.8 & 2.5 & 4.125 & 312.5 & 0 \\
\hline
\end{tabular}

Table. 2 Cultural characteristics of phosphate solubilizing bacterial isolates

\begin{tabular}{|l|l|l|}
\hline S. No. & Name of isolate & Colony morphology \\
\hline 1. & $\begin{array}{l}\text { Isolate PSB 11, PSB 16, } \\
\text { PSB 51 }\end{array}$ & Medium, red-brown, irregular, mucoid, undulate, flat \\
\hline 2. & Isolate PSB 55 & Small, yellow, circular, smooth, entire, raised \\
\hline 3. & Isolate PSB 91 & Medium, off white, watery, irregular, raised \\
\hline
\end{tabular}

Table.3 Biochemical characteristics of phosphate solubilizing bacterial isolates

\begin{tabular}{|c|c|c|c|c|c|c|}
\hline \multirow{2}{*}{$\begin{array}{l}\text { S. } \\
\text { No. }\end{array}$} & \multirow[t]{2}{*}{ Biochemical test } & \multicolumn{5}{|c|}{ Phosphate solubilizing isolates } \\
\hline & & PSB 11 & PSB 16 & PSB 51 & PSB 55 & PSB 91 \\
\hline 1 & Catalase test & + & + & + & + & + \\
\hline 2 & Cytochrome oxidase reaction & + & + & + & + & - \\
\hline 3 & Oxidation fermentation media & + & + & + & - & - \\
\hline 4 & Nitrate Reduction test & + & + & + & + & + \\
\hline 5 & Citrate utilization test & + & + & + & + & + \\
\hline 6 & Arginine hydrolysis & + & + & + & + & + \\
\hline 7 & Gelatin liquification & + & + & + & - & + \\
\hline 8 & Starch hydrolysis & - & - & - & - & - \\
\hline 9 & Esculin hydrolysis & + & - & - & - & + \\
\hline 10 & Methyl Red test & - & - & - & - & - \\
\hline 11 & Voges-Proskauer test & - & - & - & - & + \\
\hline 12 & Casein hydrolysis & - & - & - & + & - \\
\hline \multirow[t]{13}{*}{13} & Carbohydrate fermentation & & & & & \\
\hline & Arabinose & - & - & - & - & - \\
\hline & Cellibiose & - & - & - & - & + \\
\hline & Glucose & + & + & + & + & - \\
\hline & Lactose & - & - & - & - & - \\
\hline & Mellibiose & - & - & - & - & - \\
\hline & Maltose & - & - & - & - & + \\
\hline & Mannose & - & - & - & - & + \\
\hline & Sorbitol & - & - & - & - & - \\
\hline & Sucrose & - & - & - & - & - \\
\hline & Raffinose & - & - & - & - & + \\
\hline & Rhamnose & - & - & - & - & + \\
\hline & Xylose & - & - & - & - & - \\
\hline \multirow[t]{2}{*}{14} & $\begin{array}{l}\text { Growth on } \\
\text { (a) Cetramide agar }\end{array}$ & + & + & + & + & - \\
\hline & (b) McConkey agar & + & + & + & + & + \\
\hline \multirow[t]{2}{*}{15} & $\begin{array}{l}\text { Pigment production on } \\
\text { (a) King's A media }\end{array}$ & + & + & + & - & - \\
\hline & (b) King's B media & + & + & + & - & - \\
\hline
\end{tabular}


Table.4 Molecular characterization of phosphate solubilizing bacterial isolates

\begin{tabular}{|l|l|l|l|}
\hline S. No. & Name of the isolate & \multicolumn{1}{|c|}{ Identification of isolates } & \multicolumn{1}{|c|}{ Accession no. } \\
\hline 1 & PSB 11 & Pseudomonas aeruginosa PSB 11 & KY640213 \\
\hline 2 & PSB 16 & Pseudomonas aeruginosa PSB 16 & KY640214 \\
\hline 3 & PSB 51 & Pseudomonas aeruginosa PSB 51 & KY562850 \\
\hline 4 & PSB 55 & Pseudomonas oryzihabitans PSB 55 & KY562851 \\
\hline 5 & PSB 91 & Cronobacter universalis PSB 91 & KY568089 \\
\hline
\end{tabular}

Fig.1 Phosphate solubilizing bacterial isolates recovered on PVK agar from rhizosphere of Different plants growing in tailing dam of Zawar mines

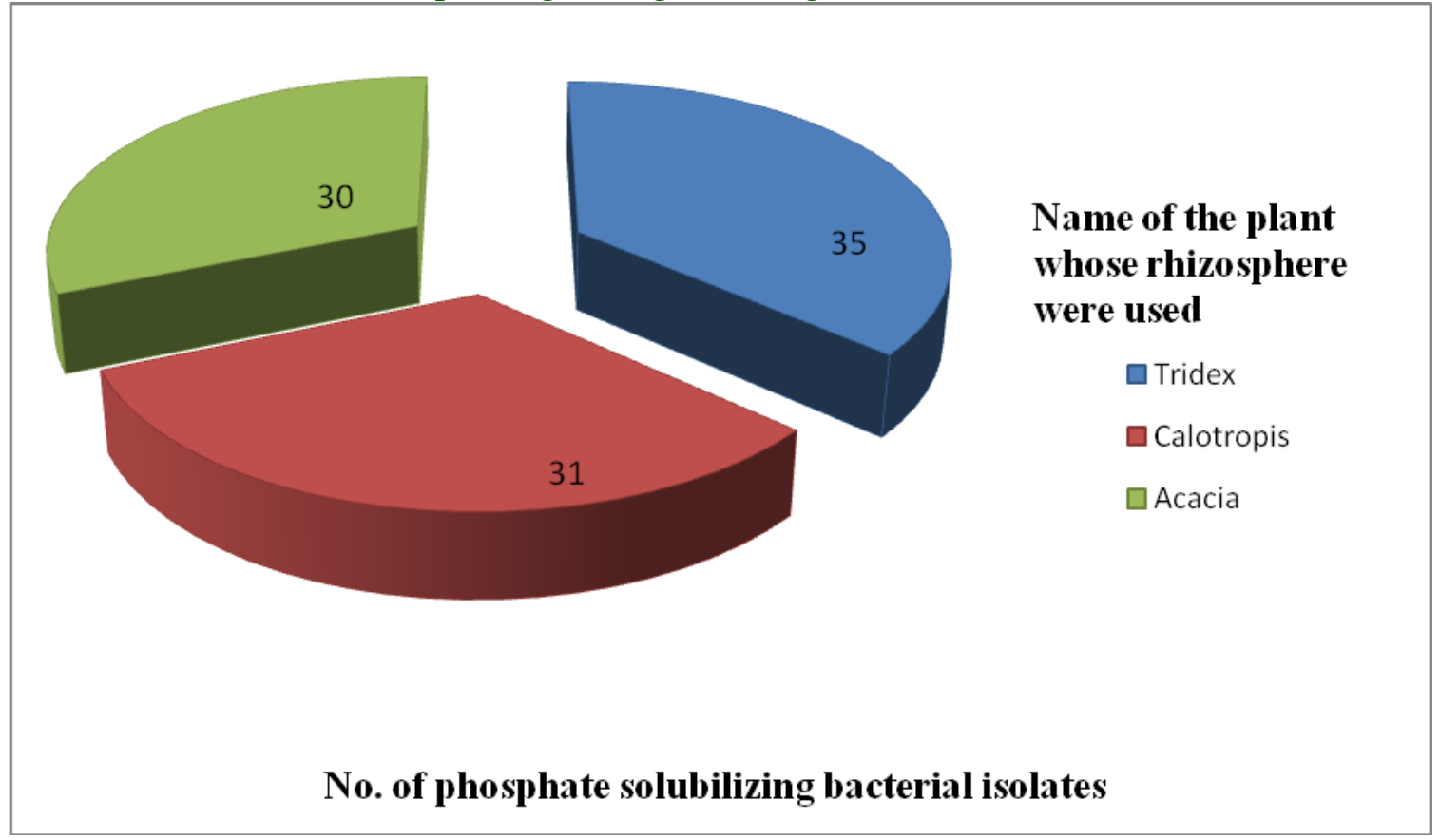

Fig.2 Minimum inhibitory concentration of $\mathrm{ZnSO}_{4} .7 \mathrm{H}_{2} \mathrm{O}$ exhibited by Phosphate solubilizing isolates

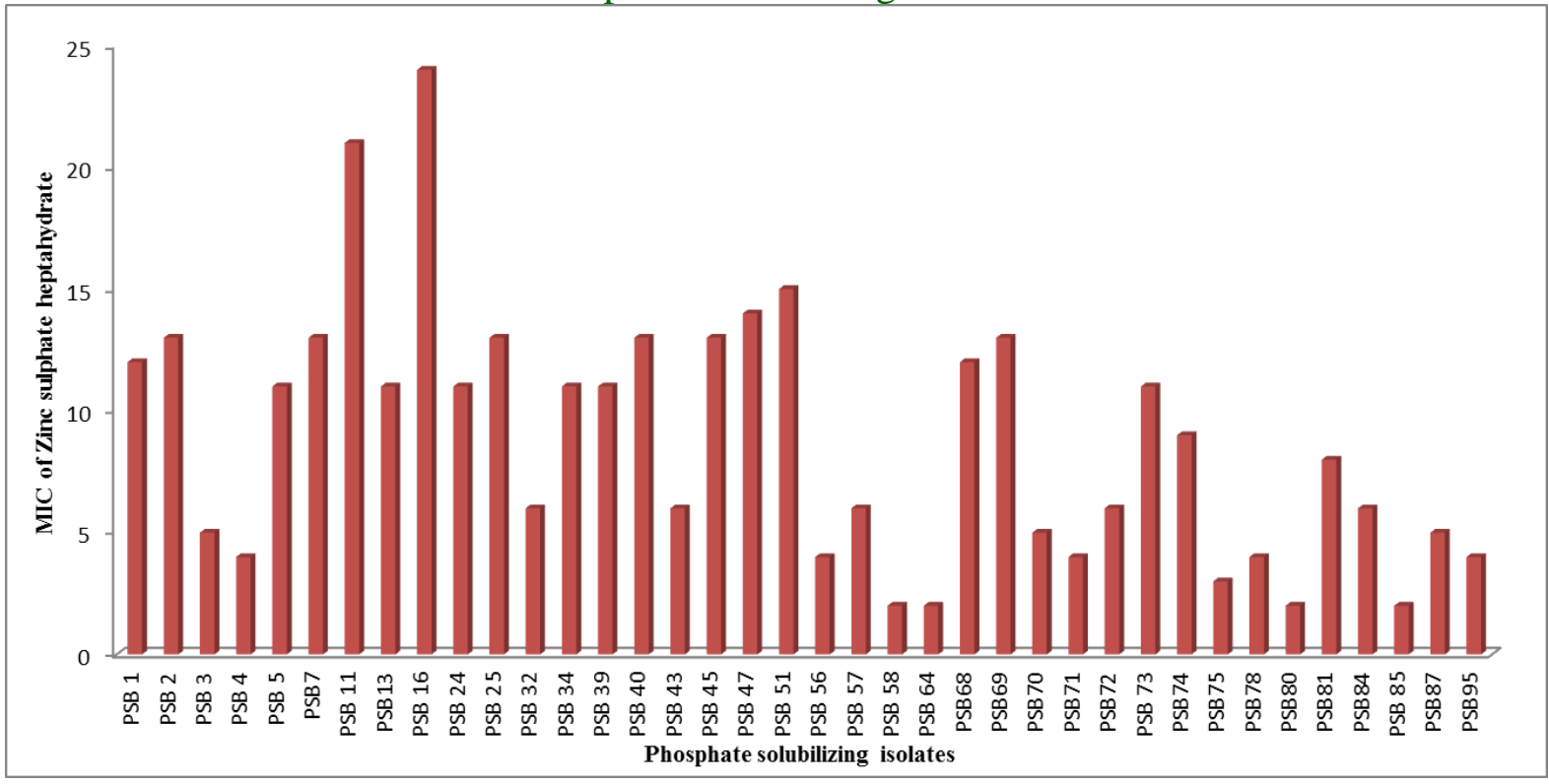




\section{Identification of phosphate solubilizing} bacteria

The cultural characteristics of all the 5 isolates were studied by growing the isolates on nutrient agar. A total of 3 different types of bacterial colonies were recovered on nutrient agar for the five phosphate solubilizing isolates as presented in table 2. All the five phosphate solubilizing isolates were found to be gram-negative and rod shaped as well as they showed positive results for catalase test. A total of four (PSB11, PSB16, PSB51, PSB55) out of five isolates were found to be positive for oxidase test whereas PSB 91 was found negative. All the five isolates reduced nitrate, utilized citrate and arginine while found negative for starch hydrolysis and MR test. PSB 55 was unable to liquefy gelatin while rest of the four isolates were found positive for the test. On contrary to this, PSB 55hydrolyzed esculin and casein whereas the other four isolates were found negative for these two tests. Only PSB 91 was found to be positive for Voges-Proskauer test among all the five isolates. All the five isolates showed growth on McConkey agar but only four isolates (PSB11, PSB16, PSB51, PSB55) out of five were able to grow on cetrimide agar. However, only three isolates PSB11, PSB16, PSB51 produced pigment on King's A and King's B medium whereas PSB55and PSB91 failed to do so. The carbohydrate pattern for the five isolates was as presented in table 3 . The results obtained from biochemical tests and the carbohydrate fermentation tests (for the five isolates) were matched with Bergey's Manual of Systematics Bacteriology (2005). The tentatively identified genus for four phosphate solubilizing bacteria PSB 11, PSB 16, PSB51 and PSB 55 was Pseudomonas whereas PSB 91 belonged to Cronobacter respectively.

Molecular characterization of all the five phosphate solubilizing isolates was done by
16S rRNA sequencing. The 16S rRNA sequence of the isolated DNA was amplified using universal primers, 27F (5'AGAGTTTGATCCTGGCTCAG-3') and 1492R (5'CGGTTACCTTGTTACGACTT3') (Weisberg et al., 1991) in PCR and an amplified product of $1.5 \mathrm{~kb}$ was obtained. The amplified products of all the five were submitted to Bangalore Genei Pvt. Ltd., Bangalore (India) for sequencing. The partial sequenced genes of the isolates were compared with available standard sequences of bacterial lineages in the NCBI Genbank using nBLAST. The analysis showed that four strains (PSB 11, PSB 16, PSB 51 and PSB 55) were closed to the members of genus Pseudomonas and one strain (PSB 91) showed similarity with Cronobacter species.

The three phosphate solubilizing isolates PSB 11, PSB 16 and PSB 51 showed 99\% similarity to Pseudomonas aeruginosa therefore these three isolates were identified as Pseudomonas aeruginosa PSB 11, Pseudomonas aeruginosa PSB 16 and $P$. aeruginosa PSB 51. Isolate PSB 55 showed 99\% similarity to Pseudomonas oryzihabitans and isolate PSB 91 showed 98\% similarity to Cronobacter universalis.

Therefore, isolate PSB 55 was identified as Pseudomonas oryzihabitans PSB 55 and isolate PSB 91 was identified as Cronobacter universalis PSB 91. The nucleotide sequences of all the five isolates were deposited in NCBI gene bank and the accession no. assigned to them are listed in table 4.

The use of universal primers (27 $\mathrm{F}$ and 1492 R) along with $16 \mathrm{~S}$ rRNA sequencing has been proved to be an authentic technique for molecular characterization of isolates.

Several researchers (Elijah et al., 2014; Mahmoud MSK, 2016) had used this technique previously for molecular 
characterization. The universal primer $27 \mathrm{~F}$ and $1492 \mathrm{R}$ was initially designed by Weisberg et al., (1991). His studies revealed that the primer pair designated fDl and $\mathrm{rPl}$ (now known as 27F and $1492 \mathrm{R}$ ) was capable of amplifying a wide variety of bacterial taxa as compared to the other primer pairs used in the study. Chikere and Ekwuabu (2014) isolated autochthonous hydrocarbon utilizing bacteria in oil-polluted sites of Bodo Community, Nigeria and performed their molecular characterization using universal primers $27 \mathrm{~F}$ and $1492 \mathrm{R}$. They reported that the use of $16 \mathrm{~S}$ rRNA in the characterization of microorganisms is more reliable and sensitive than culture-dependent techniques alone. Therefore, in the present study molecular characterization based on $16 \mathrm{~S}$ rRNA using universal primer $(27 \mathrm{~F}$ and 1492R) has been proved to be useful for the identification of organisms upto the species level.

The present study has demonstrated that bacterial communities which lived in association with plant rhizosphere are highly effective in solubilizing tri calcium phosphate. The three phosphate solubilizing isolates can also withstand high concentrations of zinc which may support the biosorption of the heavy metals by the plants and reduce the metal toxicity in soil. Owing to these abilities the isolates can be exploited for their plant growth promoting activities so that they can support the bioremediation and revegetation of zinc contaminated soils in future.

\section{References}

Ahemad, M., Saghir, M. 2011. Effects of insecticides on plant-growth-promoting activities of phosphate solubilizing rhizobacterium Klebsiella sp. Strain PS19. Pest Biochem Physiol. 100: 51-56.

Archana, D.S., Nandish, M.S., Savalagi, V.P., Alagawadi, A.R. 2013. Characterization of potassium solubilizing bacteria (KSB) from rhizosphere soil. Bioinfolet-Quart. J. Life Sci., 10: 248-257.

Bergey's Manual of Systemic Bacteriology. Springer, USA, $2^{\text {nd }}$ Ed. 2005.

Chen, Y. P., Rekha, P. D., Arun, A. B., Shen, F. T., Lai, W. A., Young, C.C. 2005. Phosphate solubilizing bacteria from subtropical soil and their tricalcium phosphate solubilizing abilities. Appl Soil Ecol. 34:33-41.

Chikere, C. B., Ekwuabu, C. B. 2014. Molecular characterization of autochthonous hydrocarbon utilizing bacteria in oilpolluted sites at Bodo Community, Ogoni land, Niger Delta, Nigeria. Nig J. Biotech. 27: $28-33$.

Elijah, A.I., Atanda, O.O., Popoola, A.R., Uzochukwu, S.V.A. 2014. Molecular characterization and potential of bacterial species associated with cassava waste. Nig food J. 32(2): $56-65$.

Giller, K.E., Witter, E., Mcgrath, S.P. 1998. Toxicity of heavy metals to microorganisms and microbial processes in agricultural soils. Soil Biol. Biochem., 30(10-11): 1389-1414.

B.R. Glick. 2012. Plant Growth-Promoting Bacteria: Mechanisms and application. Shindawi Publishing Corporation, Scientifica.

Joseph, B., Patra, R.R., Lawrence, R. 2007. Characterization of plant growth promoting rhizobacteria associated with chickpea (Cicer arietinum L.). Intern J Plant Produc 2: 141-152.

Luli, G.W., Talnagi, J.W., Strohl, W.R., Pfister, R.M. 1983. Hexavalent chromium resistant bacteria isolated from river sediments. Appl. Environ. Microbiol., 46(4):846-854.

Mahmoud, M.S.K. 2016. Characterization and molecular identification of unknown bacteria isolated from outlet of Arab El Madabegh sewage treatment Plant in Assiut City, Egypt J. Eco. Heal. Env. 4(1): $1-5$

Mendez, M.O., Raina, M. Maier. 2007. Phytostabilization of mine tailings in arid and semiarid environments - an emerging 
remediation technology. Environ. Heal Perspec., 116 (3).

Mursyida, E., Mubarik, N.R., Tjahjoleksono, A. 2015. Selection and identification of phosphate-potassium solubilizing bacteria from the area around the limestone mining in Cirebon quarry. Res. J. Microbiol.10: 270-279.

Nguyen, C., Yan, W., Tacon, F.Le, Lapayrie, F., 1992. Genetic variability of phosphate solubilising activity by monocaryotic and dicaryotic mycelia of the ectomycorrhizal fungus Laccaria bicolor (Maire) P.D. Orton. Plant and Soil, 143: 193-199.

Onyia, C.E., Anyanwu, C.U. 2013.Comparative study on solubilization of tri-calcium phosphate (TCP) by phosphate solubilizing fungi (PSF) isolated from Nsukka pepper plant rhizosphere and root free soil. J Feast Fungal Res,, 4(5):52-57.

Outten, C. E., Oõhalloran, and T.V.2000.Femtomolar Sensitivity of Metalloregulatory Proteins Controlling Zinc Homeostasis. Science 292: $2488-$ 2492.

Pal, A., Dutta, S., Mukherjee, P. K., Paul, A. K. 2005. Occurrence of heavy metalresistance in microflora from serpentine soil of Andaman. J. Basic Microbiol. 45 (3): 207-218.

Pérez, E., Sulbarán, M., Ball, M.M., Yarzábal, L.A. 2007. Isolation and characterization of mineral phosphate-solubilizing bacteria naturally colonizing a limonitic crust in the south-eastern Venezuelan region. Soil Biol. Biochem. 39: 2905-2914.
Pikovskaya, R.I., 1948. Mobilization of phosphorus in soil in connection with vital activity of some microbial species. Microbiol 17: 362-370.

Pospiech, A., Neumann, B., 1995. A versatile quick-prep of genomic DNA from grampositive bacteria. Trends Gen. 11(6): 217218.

Ramachandran, K., Srinivasan, V., Hamza, S., Anandaraj, M. 2007. Phosphate solubilizing bacteria isolated from the rhizosphere soil and its growth promotion on black pepper (Piper nigrum L.) Cutting. Plant Soil Sci., 102: 325 -331.

Reyes, I., Bernier, L., Simard, R.R., Antoun, H. 1999. Effect of nitrogen source on the solubilization of different inorganic phosphates by an isolate of Penicillium rugulosum and two UV-induced mutants. FEMS Microbiol Ecol. 28:281-290.

Wani P.A., Khan, M.S., Zaidi, A. 2008. Chromium-reducing and plant growthpromoting Mesorhizobium improves chickpea growth in chromium-amended soil. Biotechnol. Lett., 30:159-163.

Weisburg, W.G., Barns, S.M., Pelletier, D.A., Lane, D.J., 1991. 16S ribosomal amplification for phylogenetic study. $J$ Bacteriol.173, 697-703.

Wcislo, E., Ioven, D., Kucharski, R., Szdzuj, J. 2002. Human health risk assessment case study: an abandoned metal smelter site in Poland. Chem., 47: 507-515.

\section{How to cite this article:}

Monica Sen and Harshada Joshi. 2017. Characterization of Phosphate Solubilizing Bacteria Isolated from Mine Tailings of Zawar Mines, Udaipur, India. Int.J.Curr.Microbiol.App.Sci. 6(8): 588-596. doi: https://doi.org/10.20546/ijcmas.2017.608.076 